\title{
An Interview with Julia G. Costello
}

\author{
Glenn J. Farris 두
}

Accepted: 22 June 2021 / Published online: 26 October 2021

(C) Society for Historical Archaeology 2021

Julia Garvin Costello (Fig. 1) was raised primarily in New York and Maryland. For college, she went to St. Lawrence University in upstate New York, graduating with a B.A. in sociology in 1968. Being of an adventurous nature, she traveled extensively in Europe and the Middle East following graduation. This included time spent in Lebanon, where exposure to the local archaeology came to have a large influence on her subsequent professional career. After a ski season working in Vail, Colorado, Julia turned to academia and was accepted into the anthropology program at the University of Denver. She received her M.A. in 1972, with her thesis on a computer analysis of projectile points.

Following up on an earlier invitation from Dr. James B, Pritchard of the University of Pennsylvania Museum, Julia joined a variety of excavation projects in Lebanon in the early 1970s, where she was able to parlay her skills in computer-data input and artifact analysis to enhance her value to the teams she joined. Likewise, she made deep personal, lifelong connections with individuals who later became leaders in the archaeology of the region.

The outbreak of hostilities in Lebanon in 1974 shut down all archaeology projects, and so Julia returned

\section{G. J. Farris $(\square)$}

California State Parks: California Department of Parks and Recreation (retired), 2425 Elendil Lane, Davis, CA 95616, U.S.A.

e-mail: gfarris@omsoft.com to the United States. She followed up on a friend's invitation to come out to California to visit. Whereas she had hoped that things would blow over soon in the Middle East and that she could return there, the unsettled conditions dragged on. Julia decided that she needed to move on with her career. This led her to enter the doctoral program at the University of California, Santa Barbara (UCSB). Like all of the UC universities of the time, prehistoric archaeology dominated the scene. Julia entered as a student of Albert Spaulding, famous for his focus on analytical techniques in archaeology, which made Julia's background in analysis and computer applications particularly appealing.

As it happened, Julia got the opportunity to work on several projects related to the early Spanish era history of California, both at the Presidio of Santa Barbara and then at the first site of Mission La Purisima Concepción in Lompoc. She developed a passion for mission archaeology that moved her into the realm of historical archaeology. Spaulding was not interested in working with an historical archaeologist, and so their professor-student connection was unilaterally terminated. Fortunately, Professor Michael Glassow at UCSB was willing to work out a new arrangement for Julia to pursue her degree with more of an historical perspective. At the time, Jim Deetz was teaching at UC Berkeley and agreed to be on her dissertation committee. Another valuable member of her committee was physical anthropologist Philip Walker. 


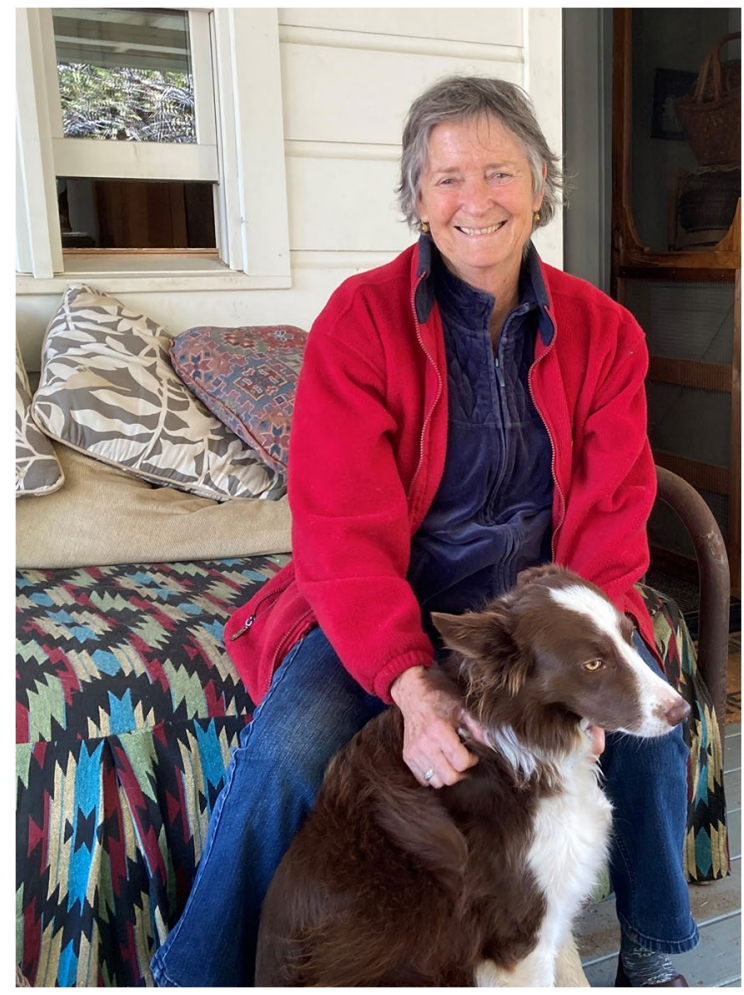

Fig. 1 Julia Costello at home with her dog, Ruby. (Photo by Glenn Farris, 2021.)

In 1978 an enormous cultural resources project related to the construction of the New Melones Reservoir in the "Gold Country" of California came online, and Julia was hired to lead the research into the historical archaeology, working together with a prehistorian, Harvey Crew. This high-pressure project (both in scope and limited time available) brought her into contact with a large number of archaeologists working in California. A major plus of the project was that it introduced Julia to life in the small towns of Calaveras and Tuolumne counties with which she fell in love, and where she has made her home right up to present. Fitting right in with the California lifestyle, Julia could be seen cruising to various parts of the state in her treasured VW van decorated with flames on the sides and nicknamed "El Fuego." In 1977 she and her sister drove it down for a year's sojourn in Mexico and Guatemala in the halcyon times prior to the dangers of narco-traffickers.

When the New Melones Project came to an end, Julia entered into a partnership with Judith Marvin, an historian and county archivist with whom she had been working for several years. Their cultural resources management company, Foothill Resources, was much needed to fill a niche for the study of historical sites, especially in California. Julia also developed an eclectic interest in various ethnic sites, particularly Chinese, but also Italian, and worked on projects throughout the state: Los Angeles, the Owens Valley, Mission Santa Inés, the Channel Islands, the Sacramento-San Joaquin Delta, the Sierra Nevada, and many more. Julia has worked closely with historians over the years, including, of course, Judith Marvin, but also with Paul Friedman and later with Steven Wee and Rand Herbert of JRP Historical Consulting, and also Edna Kimbro and Charlene Duval.

Simultaneously, her renown as an historical archaeologist brought an invitation to serve as a commissioner on the California State Historic Resources Commission, where she served for six years (1979-1984). Julia was chairperson of the commission in 1981. This experience broadened her perspectives and led to a greater understanding and appreciation of the built environment and the wide range of historical structures found throughout California. Knox Mellon was the state historic preservation officer at the time and had made a point of selecting Julia as the first person on the board to represent historical archaeology.

Julia was also an active participant in a number of professional societies. She served on the board of the Society for Historical Archaeology (SHA) from 1985 to 1993 , including a term as president. She also was an associate editor for Historical Archaeology. Soon after doing her tour of duty at SHA, Julia was approached by the Society for California Archaeology (SCA) to run for president of that organization. She served as president from 1994 to 1995 and was on the board from 1993 to 1996. Recently, Julia received the Frederickson Award for Lifetime Achievement in California Archaeology. In addition to these organizations, Julia has been very active in the California Missions Studies Association, on whose board she also served. She was presented with the prestigious Kimbro Award in appreciation of her contributions and scholarship. Such willingness to contribute to various organizations is still alive and well, as she now serves on the Calaveras Heritage Commission and is archivist for the Mokelumne Hill History Society.

Her interest in the history of California before the Gold Rush, during Spanish and Mexican rule, continued beyond her early work at the Presidio of Santa Barbara, Mission La Purísma Vieja, and Mission San Antonio. She also did a major excavation at Mission Santa Inés and later collaborated with historian Edna Kimbro in preparing a national 
historic landmark document for the mission. When Edna came down with cancer that resulted in her premature death, she had been in the midst of writing a major study for the Getty Conservation Institute: The California Missions: History, Art, and Preservation. Julia supplied the missing chapters and carried the manuscript through to publication (Kimbro and Costello 2009). She has continued a close working and personal relationship with Edna's friend and colleague, historian Charlene Duval.

Leading up to the Columbian quincentenary (1992), David Hurst Thomas organized a three-volume study titled "Columbian Consequences," and asked Julia to coordinate the California contributions. She has also collaborated on a great many other publications. One classic work, coauthored with Mary Maniery, is Rice Bowls in the Delta, which featured a major collection of Chinese and Japanese ceramics excavated on a town site in the Sacramento-San Joaquin Delta (Costello and Maniery 1988). This work was especially important because little study had previously been conducted on Japanese ceramics found on California worksites. Julia has continued her interest in Chinese sites in many parts of the state.

Finding ways to better return the results of archaeological labors to the public has been a key interest for Julia. Early on (1983), the Bureau of Reclamation published her Melones: A Story of a Stanislaus River Town, based on the extensive work at the New Melones Project (Costello 1983). She also developed dramatizations of historical, transcribed dialogues of real people to compliment features and artifacts found on sites. These voices were frequently of overlooked populations: Italian farmers, urban prostitutes, or, in one case, testimony by Paiute people who had been forced off their land in the Owens Valley in the early 20th century. The dialogues were presented at SHA and SCA conferences, where she enlisted the talents of Judy Tordoff and Adrian Praetzellis to read roles in the script.

Keeping in touch with her archaeological friends in the Middle East, especially Leila Badre and Patricia Bikai, has led to several opportunities to return to Lebanon and Jordan to work on various projects, including a Phoenician temple in Tyre and an ancient mosque in Jordan. Julia was called on to organize a National Register program for Jordan funded by the U.S. Information Agency.

Other activities in her "retirement" have involved recording sites in the Gold Country where she lives and volunteering on a program using trained dogs to locate cremains left behind in homes destroyed by the recent massive fires in California.
Our interview took place on a beautiful January day in 2021 in the California foothill town of Mokelumne Hill in the midst of the COVID-19 pandemic. After the interview we went for a walk around the historic landscape accompanied by Julia's dog Ruby, a border collie (Fig. 1). Our path took us by an old 1850s hotel and down to the public library, which was being decorated by a local artist with plenty of input from Julia. Of course, she knew everyone we met.

I want to express special thanks to Mary McNamera for her excellent transcriptions of the audio tapes and to Rebecca Yamin for her many helpful editing suggestions.

\section{Interview}

FARRIS: This interview is for the Society for Historical Archaeology's journal, Historical Archaeology. Julia, let's start with a major question of what brought you to archaeology?

COSTELLO: I believe it was serendipity and probably some natural inclination. In my sophomore year in college I wanted a class that would allow me to play bridge with my friends between 10 and 11 . There was an anthropology course that fit my requirements, and once having taken that I was hooked. I didn't see anything more fascinating than the study of humankind, so later when I went to graduate school I enrolled in anthropology and then began to specialize in archaeology.

\section{And your undergraduate work was at?}

COSTELLO: St. Lawrence University in the town of Canton in upstate New York.

Your initial experience was in Middle Eastern archaeology?

COSTELLO: No, I began in prehistoric archaeology. When I graduated from St. Lawrence, I took a year off, as many of us did, and hitchhiked around Europe and the Middle East. After a year of bumming around I got a waitressing job in Vail, Colorado, for a season. Although I got to be a pretty good skier, I felt that Vail was the cultural nadir of the world, so I went right down the Rocky Mountains to the University of Denver and applied to graduate school. The anthropology department was headed by Dr. Arnold Withers, an archaeologist who focused on Southwest prehistory. Dr. Kate Peck Kent was also there and was wonderful. In lieu of another language for the M.A. requirements, I opted to learn computer programming. Working with the math department, I did an analysis of projectile points from the University of Colorado collections. My 1972 M.A. thesis was "A Cluster Analysis of Projectile Points from the Colorado Central Front Range." 


\section{But then you did move into Middle Eastern archaeology at some point? \\ COSTELLO: Yes, I had an opportunity through fam-} ily connections in Lebanon. When I had been in my post-college bumming-around years, my grandmother was living in Beirut. While I was visiting her in 1968, her good friend, Dr. James B. Pritchard, from the University of Pennsylvania Museum, was passing through. He always spent time with my grandmother, who showed him sites she found during her explorations. She was an amateur "sleuther." I told him that I was thinking of graduate school, and he said: "Well, when you get your degree contact me and I'd be glad to have you on one of my teams over here." So three years and many adventures later I finished my M.A. and wrote him a letter, saying: 'I' $m$ Mary Eddy's granddaughter, we met in Lebanon, and do you have a place for me?" And because I had designed the projectile-point analysis and they were just beginning to computerize their ceramic typologies, he decided that he could use a young analytic person to help make coding sheets for the ceramics. And so he put me on his team, but I'm also quite sure it was because he knew my grandmother very well.

\section{So how long did you work there?}

COSTELLO: I remained in Lebanon for about two years. I worked two seasons for Dr. Pritchard just south village of Sarafand Sidon at the ancient site of Sarepta, near the village of Sarafand. Some of my dearest and oldest friends were made on those early digs in Lebanon. This may be similar to a military platoon that you never forget because you were in the war zone. We were out there on the frontier, digging these fabulous Phoenician, Bronze Age, and Roman sites. These early friends included Leila Badre, who was later the director of the American University of Beirut (AUB) Museum; Patricia Maynor Bikai, famous for her ceramic studies; and Martha Sharp Joukowsky, who subsequently went on to teach at Brown and excavated at Petra. We were all pre-Ph.D. archaeologists, digging in the dirt and experiencing fabulous sites. It was also an exciting and fun time to be in the city of Beirut. Called the "Paris of the Middle East," it was a hub of political and social activities. I also worked for the Lebanese Department of Antiquities on a Roman pot site in Tripoli in the north and spent two seasons working for the American University of Beirut at the Bronze Age Tell El Ghassil site in the Bekaa Valley with Leila Badre. Two critical skills learned in those early years I have relied on throughout my career: careful excavation by natural stratigraphy and developing meaningful artifact typologies for analysis, particularly ceramics.

I thought I would be the next family member to settle in Lebanon; my grandparents and great-grandparents and great-great-grandparents had all lived in Lebanon and are buried there. They were among the missionaries who founded schools and universities. My grandfather, Colonel Eddy, was born in the town of Sidon in what is now Lebanon, but was then Syria in the Ottoman Empire. Like many children of missionaries, he was recruited into the U.S. Foreign Service. He went into the Office of Strategic Services (OSS, precursor to the CIA), formed during World War II, as head of the North African Campaign. He had previously gone to the States to get his B.A. and Ph.D. degrees from Princeton and then taught at the American University of Cairo. He was fluent in classical Arabic and colloquial Arabic, and had grown up in Middle Eastern cultures. He then became the first U.S. ambassador to Saudi Arabia, where he worked with King Ibn Saud in integrating the new kingdom into the modern world. He was a much-admired man in the State Department and with our Arab allies.

During our last season in Beirut in 1974 the war was beginning. and we were under curfew, except for a couple of hours every day. One afternoon we made a run to the AUB Museum to retrieve our artifacts out of the basement. We were in Martha Joukowsky's convertible, bantering in Arabic trying to pass military checkpoints with the back of the car full of boxes and people with guns standing around. We got the boxes back to our rooms at the Myrntom House Hotel, where most of the crew was staying, and spent a month commandeering rooms and analyzing artifacts in the dining room. Finally, Dr. Pritchard said: "Everybody's going home. We don't know how long this military conflict is going to last." We all packed our bags and locked away the artifacts at AUB. I came to California where an old college friend lived, thinking it would just be a couple of months before I could go back to Lebanon, but it was actually 20 years before Americans were allowed to return.

\section{This was all taking place in the early 1970s?}

COSTELLO: I left Lebanon in 1974; 1975 is when the war actually started, but in 1974 there were planes strafing at night and machine guns firing during the day. Several of my friends remained, though. Leila Badre, a Syrian, stayed at the American University of Beirut. Patricia Bikai and her Lebanese archaeologist husband, Pierre, stayed another year or so, and they have hairraising stories. They were directing excavations down in 
Tyre in 1975 and had to flee by car to Byblos. When I realized I wasn't going back to Lebanon I applied to the Ph.D. program at UC Santa Barbara.

Let's backtrack a little. I understand that you engaged in parachute jumping at one time. Could you tell me more about that?

COSTELLO: My older sister and I went to the University of Colorado at Boulder for summer school in 1966. She had previously made some jumps to join the Cherry Creek Reservoir skydiving club outside Denver and fell in with this jolly group. We would study during the week in Boulder and go down to Denver on weekends for the jumping. By the end of the summer I had a B license and about 50 jumps. Back at St. Lawrence that fall, I found a jump club in Brockville, Canada, about an hour and a half away from school. I would go up on weekends when the weather was good. At the University of Denver, I continued occasional skydiving and accumulated about 200 jumps. But when I moved back to California from Lebanon I never took the sport up again.

Well, although I may not be as keen on the idea of skydiving as you, another of your interests, sailing, is something I find very appealing, and you've done a lot of that too.

COSTELLO: I grew up around little boats. I love the quote from Wind in the Willows: "[T]here is nothing half so much worth doing as simply messing about in boats." At a number of meetings, especially in San Diego, you and I have skipped out on a half a day of sessions, rented a sailboat, and gone out into the bay for a pleasant sail. It's great fun.

Yes. You also went with your family to the Caribbean and did some sailing there, didn't you?

COSTELLO: I did. My New Yorker dad had always been a great whaling fan. He had all these memorabilia and knew every sea chanty I've ever heard of. But when he was in his 70s I discovered that he had never actually been on a sailboat. And I thought: "This is not going to stand!" So my husband, Jeff Tuttle, and I rented a $27 \mathrm{ft}$. sailboat in the Caribbean's Windward Islands. It came with a captain, a young man who'd grown up on the islands, who was also our cook. My father and stepmother and Jeff and I had 11 fabulous days sailing around the Windward Islands.

Returning to archaeology, how was doing your doctoral work at UC Santa Barbara?
COSTELLO: I made contacts at UCSB when I first got there in 1975, introducing myself. Brian Fagan contacted me soon afterward and said they'd gotten a call from Lompoc about a Spanish mission site and wondered if UCSB could send somebody to look at the ruins. The prehistoric archaeologists were not interested, and I had been excavating Roman sites in the Middle East, which actually are very similar. To me, the Spanish missions were archaeologically just like Rome, with pretty much the same architecture, aqueducts, and technologies. So I said I'd be glad to go look at it, and that introduced me to the world of historical archaeology. When I was hired as director of the Santa Barbara Royal Presidio excavations, my ties with UCSB became closer.

Because my M.A. had been in mathematical analysis, I was accepted into the UCSB graduate program as an analytical archaeologist with Albert Spaulding, who specialized in quantitative statistics, as my chair. But it soon became clear to Spaulding that I was interested in Spanish mission sites and what he disparaged as "historical archaeology." He had a meeting with me one day and said: "You cannot be my student anymore." He had taken a stand in publications that was stridently antihistorical archaeology, and he could not have a student in that field. At that point I remember going out of his office and up to the breezeway at North Hall and crying, just standing there thinking: "What am I going do, I've just been set adrift!" Mike Glassow then took me in, put his academic arm around me and said you can stay here and I'll be your sponsor, and we'll figure out how to get through this. He set me up with Jim Deetz at UC Berkeley as the chair of my committee, and I took courses from Jim. Mike also made a liaison with the new publichistory department at UCSB. Mike cobbled together a program for me.

Were there any particular mentors in historical archaeology available to you at UCSB?

COSTELLO: Certainly Jim Deetz, and taking his classes, which were more available for me when I moved up to northern California. Mike Glassow and Phil Walker were my main academic connections at UCSB.

\section{Phil Walker too?}

COSTELLO: Phil Walker was fabulous. He was on my dissertation committee, and we did a number of studies together. The first were burials at the Santa Barbara Presidio that we analyzed and published in 1987 in Historical Archaeology (Costello and Walker 1987). He was open to everything. Historical or 
prehistoric archaeology didn't make any difference to him, it was all the study of human beings in the past.

You mentioned a number of your memorable projects, but would you expand on that a little bit?

COSTELLO: The huge one for me in the United States was New Melones. In 1978 I moved to the Sierra Nevada foothills, where I'm living now. The project was in response to damming the Stanislaus River by the U.S. Army Corps of Engineers. Laws compelling archaeological studies before federal dams were filled had recently been enacted. The New Melones Dam Project triggered the largest archaeological study in the United States that had ever happened. It was eclipsed after a few years by the Tennessee-Tombigbee Project, but, at that time, in 1978, there had never been such an enormous archaeological undertaking. I was on a team assembled by a group called "Science Applications." As a co-principal investigator (co-PI), I was to be in charge of historical sites. Harvey Crew, your old friend from Davis, was the co-PI in charge of prehistoric sites. He had a Ph.D., I did not, but we won the contract, amazingly.

None of us were prepared to hire 100 archaeologists to look at over 1,000 sites on the $10 \mathrm{mi}$. of the Stanislaus River basin under a huge time crunch. The dam had already been built, and they were starting to fill it. We were required to address bathtub-like rings of elevations according to rising water levels. This gave us the terrible logistical problem of covering a band of elevation over the entire project area. I was an experienced field archaeologist, but I didn't know anything about recording and evaluating that many sites with difficult logistics and a huge staff.

Science Applications fired our initial PI and asked us: "What senior archaeologist in the United States could be our senior PI and save the project?" Harvey and I said to them: "You get Jim Fitting out from Michigan and he can save us." We didn't really think that they'd get Fitting out here, as he was a tenured professor, but within a month he was onsite. I don't know what they offered him, but he was quickly in charge and pulled us into shape.

Jim put us through management courses, moved our offices into a large building, rented a fleet of trucks, had people in charge of logistics and people in charge of topics we didn't even know about just to manage staff and sites. We computerized everything. The New Melones Project was like a major campaign, and those of us who worked on it remember it not always lovingly, but as a baptism by fire. It involved addressing more sites with more effort in less time than any of us had experienced. It was hard. We were also under the gun from California archaeologists. The favored local archaeologists had not won the contract, and they had us investigated by the Government Accounting Office and the Society for California Archaeology. It is difficult when your colleagues are scrutinizing you saying: "You are not up to this job" and that "the good guys didn't win" and "Who are you, anyway?" I was relatively new to California and didn't have deep connections. Harvey, however, with his degree from UC Davis, was calm and wonderful and a terrific colleague. We weathered it all, and it was both tough and memorable.

Another project I'm aware of, of course, is Mission San Antonio, where you did so much work.

COSTELLO: Mission San Antonio is a wonderful place, and I am very nostalgic about it. I had been directing the digs at the Santa Barbara Presidio at the Mission La Purisima Vieja site in Lompoc. Bob Hoover, a wonderful colleague, wanted to move beyond prehistoric archaeology. He had an opportunity to conduct excavations at Mission San Antonio, but he needed some expertise on how to dig historic and Spanish colonial sites, so he asked me to come on the team. I worked with him the first three seasons (1978-1980) and set up a system of natural stratigraphy, organized the lab, and established ceramic and other artifact typologies. However, as wonderful as those summers were, I had other projects I needed to pursue.

You've worked closely with a number of historians, tell me some highlights about these relationships.

COSTELLO: I have learned that, in general, historians are much better at doing history than archaeologists. From my earliest years at UCSB I worked with the new public-history department. In 1978, for my first large urban project, La Placita de Dolores in downtown Los Angeles, I hired M.A. student Paul Friedman as project historian. He dove into the archives and came up with maps and road-construction elevations to guide our excavations, as well as an historical context for the city and neighborhood. When I moved up here for the New Melones Project I brought Paul up as the project historian, and he was invaluable. He located all the local archives and identified the occupants of many of our sites as well as the 
region's historical development. For more focused studies we contracted with a firm of historians in Davis, employing Turentine Jackson and Steve Mikesell.

Judith (Cunningham) Marvin and I formed Foothill Resources, Ltd., in 1983, and she was the company's historian and architectural historian. Judith was archivist for Calaveras County during the New Melones Project, which is when we got to know each other. She is still an extraordinary researcher and also exemplary in reaching out to local historical societies and experts. I also worked on many projects in California with JRP Historical Consulting Services' historians Rand Herbert and Steve Wee, who are marvelous people and excellent researchers. I believe that if you're an historical archaeologist, you need to have a professional historian on your team.

Similarly, you've worked closely with local historical societies. Can you talk about some of the contributions you have been able to make?

COSTELLO: I have always been fascinated about the story of where I live, my home turf, so to speak. When you're living within an historic landscapethe Gold Rush country-you can't help but become involved. Our company is based in rural Calaveras County, which used to be somewhat provincial when it came to implementing environmental study requirements. In the early years, when a local project required an archaeological or historical study, often no companies responded. Judith and I would then step forward and contract for its completion. We did not want the county to run into problems finding a consulting firm, and we wanted to set a high bar for what reports should look like. It was our county, and we didn't want some important historic site to be overlooked.

In the small town of Mokelumne Hill, where I live, there is an historical society maintained by a small, dedicated group. Our archives of primary and secondary documents are housed in the new town library. We digitized some 2,000 photographs and put them on a searchable database and conducted oral interviews with community old timers. Recently we purchased 5 ac. of our historic Chinatown, made possible by a bequest and good investments. We are developing these into public, historic, open spaces that people can enjoy.

A new undertaking for me was to help set up and manage the Website < https://www.CalaverasHistory. org $>$ through the Calaveras Heritage Council. Here we can post accurate information for the public to access, much of it already compiled during environmental studies. We also post historic maps and documents and provide links to other online material. People don't go to archives or museums as much anymore, they go online with their questions. It is an interesting project, but with a steep learning curve for me.

Many archaeologists have been leery about working with metal detectionists; however, you had a very useful collaboration with them on the site of Calaveras Big Trees State Historic Park.

COSTELLO: It was Doug Scott who encouraged me to use metal detectionists. He had just completed his big project at the Custer Battlefield site where they chronicled every bullet, identified the gun it came from, and reconstructed where everybody was shooting from. So I said: "Doug, how do I do this? I am looking for a site up at Calaveras Big Trees State Historic Park where the duff on the ground is some 18 in. thick. I'm going to need to use metal detectors to find the nails to deduce where the old cottage was." Doug gave me contact information for a Sacramento metal-detection club. $\mathrm{He}$ explained that metal detectionists have the best high-tech equipment and practice using it all the time.

However, Doug also advised me to set up transects to walk and have them partner with an archaeologist. You want them walking together when they get a hit on something and uncover it, so there is no temptation on the rare chance the find is something fabulous. And so, that's what we did at Calaveras Big Trees in 1987, and I have used metal detectionists on a number of sites since then with good results. They like having a scientific application for their talents and their skills, to be thanked for their efforts, and mentioned in reports, but you do have to have some protocols.

You served as president of both the Society for Historical Archaeology and the Society for California Archaeology. What were some of the highlights of those experiences?

COSTELLO: Primarily, it was the wonderful people I met and worked with in the organizations. The SHA Board members were all over the U.S., Canada, and other countries and were fabulously interesting, smart, dedicated people. Collaborating on all aspects of running a society left me a network of folks that became 
life-long friends. And in California the same thing, these are the people in the trenches with you for your tour of duty, and you all do the best job you can.

At the SHA, my board member and president's terms (1985-1993) coincided with a confrontation between underwater archaeologists and terrestrial archaeologists. Our members who were with government agencies, National Park Service, and others were adamant that anybody who collaborated with a treasure hunter be ostracized. Others argued that, if archaeologists did not participate in salvage excavations, we were going to lose all of the data on those shipwrecks. That was a disagreement that we had to ride out, and we almost had a schism where the underwater archaeologists separated from the SHA. But our annual meetings are still identified as the conference on historical and underwater archaeology, and that almost fell apart under my tenure. I learned a lot about underwater politics.

Then you moved into the Society for California Archaeology.

COSTELLO: I believe the year I got off the SHA Board the SCA asked me if I would run for president. I said: "I need a break," but instead of a break I was elected SHA President. After that term was over, the SCA asked me again, and I said I would run. What I discovered was that I had learned a lot at the SHA, which, at that time, was a more sophisticated organization than the SCA. I came into the SCA office with expectations for how a society should be run and, as a result, implemented a number of new things. We developed a membership list with names and addresses available to everyone. We upgraded our treasurer's duties from simply balancing a checkbook to keeping spreadsheets on spending categories. We also instituted the silent auction because it was such a big success at the SHA that I thought it would also work in California. And it did.

The president got to choose the banquet speaker at the annual meeting and I asked Tom Layton to perform his Chatauqua play on the ship Frolic - a big hit.

And you served on California's State Historical Resources Commission as a member and even chair. What brought that about?

COSTELLO: Actually, this brings up Knox Mellon, who we just learned has passed away. Knox was the state historic preservation officer at the time I was co-PI on the New Melones Project in 1979. The office of historic preservation decided they needed a slot on the commission for an historical archaeologist; they had a prehistoric archaeologist, but they had nobody representing the historic period. I received an invitation to apply, and Carlotta Mellon, Governor Jerry Brown's appointment secretary, called and set up a date and time a couple of weeks away for me to come to Sacramento for an interview. You have to picture that I'm in the middle of the New Melones Project, which is under enormous time pressure with the rising waters of the reservoir and hundreds of sites to study. So through the grapevine I heard that the other person they were interviewing for the historical-archaeology seat on the commission was Jim Deetz. And I thought, well, Jim Deetz is chair of my dissertation committee and perhaps the best-known historical archaeologist of the United States. Of course he's going to be appointed. So I called Carlotta and said: "You know I am really busy. I just can't take a day off to come down to Sacramento and do this interview when Jim Deetz is going to get the job." And she just pulled me up short and said: "Julia, I am telling you that you are Knox's preferred candidate. This is not something you can decline." So I was appointed, I think because they wanted someone who would see the position as an honor and work hard for the commission.

One of the terrific things about my six years on the commission was learning an enormous amount about historic architecture. Most of the commission consisted of architectural historians. We met six times a year and at every meeting we had binders of 40-50 applications to process. We'd travel all over the state to look at these buildings and listen to discussions of why they should be considered of historic significance. The commission was an immersion course in historic architecture and evaluation - what meets the National Register of Historic Places criteria and what doesn't. Many historic archaeological sites include architecture, but we tend to focus on our own areas of expertise and not pay attention to someone else's discipline. But my time on the commission softened those boundaries, and I saw that I could weigh in on architectural assessments.

Another benefit of being comfortable with historic architecture, both from being on the commission and working with Judith Marvin, was development of a design-review district for my hometown of Mokelumne Hill. This small Gold Rush town had a long-established historic district, but with the help of several others we had it transformed into an official design-review district. This took many years of work to win the support of the Calaveras County Planning Department and Board of Supervisors, and it serves as a model for other communities. I learned that once a community's historic assets are recognized as a district there are so many more tools 
to keep your community from being overrun with inappropriate intrusions or demolitions. The success of that project was a product from being on the commission.

Now you traveled widely for the archaeological heritage management committee of the International Council on Monuments and Sites (ICOMOS) on behalf of Hester Davis. Do you want to talk about that a little?

COSTELLO: I did travel for this U.S. ICOMOS Committee between 1996 and 1998. I would often sit with Hester at the ICOMOS sessions at the Society for American Archaeology meetings, and she confided to me once that though she liked the organization she was tired of traveling. I said I would love to travel, so we agreed that I would represent her on the field trips. My most memorable trips were to Sri Lanka and Mexico City. I became disillusioned with the organization after a while, however. It seemed that the meetings produced few tangible results, but were mostly providing a stage for professionals to gain prestige. After a few years I stopped going.

Your cultural resources firm, Foothill Resources, has long been a successful enterprise. How did that get started?

COSTELLO: Well we formed the company in 1983 when the New Melones Project ended. I had moved to the Sierra Nevada foothills for the project and had lived there four years. When the project ended, I went into kind of a depression, assuming I was going to have to leave and move back to Santa Barbara. Then I woke myself up thinking: "You don't have to move anywhere, you can do whatever you want from here." Cultural resources management (CRM) was just starting, and I had a wonderful working relationship with Judith Marvin, who was then the archivist of the Calaveras County Archives, and we said: "Why don't we form a company?" Initially we thought we'd give tours and other activities related to history. We formed our little company and very soon just focused on CRM projects, which were in great demand. We built a good reputation for doing historic sites work and learned about what was involved in having a company, We soon incorporated so we could take on state and federal contracts, and learned about finances with the help of some great office managers.

We decided to always stay small. There were many colleagues who started companies at the same time we did-such as JRP Consulting, Far Western Anthropological Research Group, PAR Environmental, and Pacific Legacy. Most of them grew bigger and bigger with more and more project managers and many employees. We just kept small mostly because we both liked doing research. I like to be the one out there in the field directing the research, and Judith loved being in the archives. We lived by our company's development mantra: "Do more of what you like and less of what you don't like." Most of what we didn't like was the management, so we just kept it simple. Our offices were in our own homes, we would hire people when we needed to, and had some wonderful regulars who wanted to work part-time. We became expert in historic sites and often teamed with larger companies when they needed our expertise. We were able to use their assets-trucks, lab, graphics department, GIS, paleontologists, and report production. I could direct large projects, from recording to research design and evaluation, through mitigation, by working on these teams. I'm very grateful and admiring of my friends who maintain these big companies, but I would often hear from them: "Oh, my gosh, it sounds like you're having so much fun and I never get out in the field anymore," and I would think: "Well, that was your choice, that was your call."

And it really did allow you to work all over California, which sounds fascinating. Have you felt held back due to gender considerations?

COSTELLO: I have not. But one of the things that many of us noticed is that because historical archaeology was a late comer to the field of archaeology - which had been virtually all prehistoric studies and was dominated by men-the men left it to the women to take over historical archaeology. They didn't oppose us, and many of the early historical archaeologists have been women. Instead of feeling threatened, a new category of archaeology was created. I think if I had arrived from the Middle East and tried to enter the world of prehistoric archaeology in California, I would have had a lot of pushback. I didn't do my undergraduate work here, this wasn't my rooting interest; I came in and joined a new field that established archaeologists were not interested in and so, in that way, did not feel held back by gender. Once I'd finished my doctorate, having a Ph.D. did make a difference in negotiating with agencies and their archaeologists, as it provided professional credibility.

You've also returned to the Middle East to do projects in Jordan, Lebanon, and Syria.

COSTELLO: The "Band of Sisters" forged in Lebanon in 1972-1974 rose to be leaders in their fields. They 
continued their Middle Eastern focus and were running fabulous projects. I learned that I could come on board at a crew-chief level because I knew the artifact repertoire and the culture, I was a good field archaeologist, and I spoke very bad but serviceable Arabic. And we were good friends and worked well together. I worked with Leila Badre on Tell El Ghassil in Lebanon and in Syria at Bronze Age Tell Kazel east of Tartus, where I participated in 2 seasons during Leila's 30-year anniversary of excavating the site.

I worked on two projects around Petra, Jordan, for Patricia Maynor Bikai. There we excavated a temple of an elite summer palace decorated with great carved god heads. I also directed the excavation of an ancient very early mosque, and we just recently published on that site. In 1994, I drafted a National Register program for Jordan funded by the U.S. Information Agency through the Bikais' American Center for Oriental Research in Amman.

In southern Lebanon I participated in several projects with Leila Badre. On our last one we excavated an extraordinary Phoenician temple in Tyre. However, Tyre was the Hezbollah homeland in southern Lebanon just north of Israel. When the 2013 season arrived and Leila asked me to come back, everything had changed. The previous year the U.S. had entered the war in Syria and was now actively fighting against Hezbollah. I consulted cousins who are still in the CIA who said: "Do not go! An American has no business being in southern Lebanon at this time." I did not return for that final season.

I'm fortunate for having had all these great adventures. Although all archaeology is fascinating, there is something deeply rooted and yet exotic about Middle Eastern sites: Bronze Age tells, Phoenician port cities, Nabataean temples, and Roman villas. I was lucky enough to be able to participate in these projects because of my early friendships.

Following up on that, did you face any problems as a woman leading crews in the Middle East?

COSTELLO: Back in the 1970s we were just foreign, and foreign was outside their cultural values. More recently, on my digs in the last 10 years, the workers respected you as mudera, a director, and a doctora, a scholar. They are very glad to be hired on the excavation, they're very respectful. However, being in an Arab country you had to mind your manners and dress conservatively and not go places where you might get into trouble.

So mention some ways you've been able to keep yourself busy since you've retired, in particular, how about the Cremains Project and the post-wildfire activities?

COSTELLO: Foothill Resources had worked with Canine Forensics on a couple of projects, so I was familiar with the dogs finding old cemetery boundaries. The handlers had often brought the dogs to the SCA meetings, showing us their skills.

When the Camp Fire destroyed the town of Paradise, California, in November 2018, Alex DeGeorgey of Alta Consulting, Santa Rosa, organized archaeologists to come and work with Canine Forensic teams. Our task was to visit burned-out homes and recover previously cremated remains of loved ones that had been left behind. A call went out for volunteers, and I thought: "I can do that, I want to do that." And so I went up for three weekend rotations. Each day you went to six different homes, meeting the former residents there. It was very well organized and very successful. I was frankly a bit skeptical about whether the dogs were going to find human ashes in the middle of all the other ash, but the former residents were key in providing information on where the cremains were kept in the house. The dogs were sent in to pinpoint a location. Then the archaeologists followed, and we did, indeed, learn to identify human ash. We would gather up the deposit and give them back to the very grateful relatives. Their lives at that time were a catastrophe, the whole town was a catastrophe. And here these scientists in white Tyvek suits with forensic dogs were there for them, searching for their loved one's remainstheir daughter, their mother, their brother. We gave them something more than the cremains. The whole project was so uplifting and rewarding.

So what would be some bits of advice you would offer women looking for a career in historical archaeology?

COSTELLO: I have recently been reminiscing about the field of historical archaeology with some old friends. I feel that, when we were working in the 1970s, '80s, and '90s, we were in the heyday years. Everything was new during this boom in historical archaeology fieldwork. We didn't have a typology for Chinese ceramics. We were trying to identify features of Spanish mission sites and locate outlying ranchos. Early mining technologies needed to be identified. Practically every project opened new 
doors, and we were challenged with figuring it out, and abundant CRM projects allowed us to look at types of historic-period sites that were previously not addressed. During these decades professional meeting sessions were exciting, sharing new data and techniques. Now these pioneering years of exploration and discovery are mostly over.

So my advice to a new student is to acquire a unique talent to offer a team. Learn how to do some scientific analysis technique, hone your computer skills, specialize in conservation and curation. Those kinds of talents are going to be invaluable. But a career of digging? if you want to buy a house and send your kids to college, this is probably not a wise career choice. Professionals require advanced degrees, which entail a lot of academic work. The payoff may not be in huge salaries, so you have to love what you are doing. And I'm not sure how much work is out there for new archaeologists, or how many teaching positions there will be. We don't want to just keep preparing people for careers that aren't there. So I would ask: "Why do you want to be an archaeologist?" Identify the aspect that you love: is it travel? artifacts? museum work? data analysis? Then focus on that topic.

Well that is the end of my questions. Is there anything else? Is there anything you wanted to add on? You've been pretty thorough on this.

COSTELLO: I'm proud of an innovation I introduced at both the SHA and SCA meetings: dramatizing historical narrations. Although these presentations have been categorized under "storytelling," the scripts that I wrote were not fiction. My inspiration was playwright Anna Devere Smith, who developed a documentary form called "verbatim theatre." In Twilight: Los Angeles, 1992, she interviewed people about the riots in Watts, transcribed their words, and put them into a script dialogue using exactly their words. I saw her perform this in San Francisco and was blown away. I thought, we can do that in historical archaeology where we have people's words and can illustrate them with artifacts from sites. I did my first "verbatim theatre" in 1996 at the SCA meeting- "Bread Fresh from the Oven" was on Italian ovens with the dialogue from interviews with Mother Lode Italians; Judy Tordoff helped perform the script. And "Red Light
Voices" drew on interviews from New Orleans's Storyville, illustrated with artifacts from our recent L.A. brothel excavation; here Judy and Adrian Praetzellis took roles in the performance. An historic-period Paiute ranch site we identified in the Owens Valley involved a 1915 lawsuit producing transcribed depositions that added historic voices to the archaeological remains. That project was particularly rewarding, as some years later the Paiute Indian reservation near Bishop wrote me and asked me if they could have a copy of the play. Of course I sent it to them.

I am also glad I made the effort to publish many of my research findings. The hundreds of CRM reports I authored or coauthored range from small surveys to multivolume data-recovery projects. More accessible are over 20 published articles and at least 10 books or monographs summarizing the highlights of these projects. I also tried, throughout my career, to interpret our archaeological findings for the public. The first was the popular booklet on New Melones that was reprinted several times by the Bureau of Reclamation (Costello 1983). Most recently I coauthored a beautifully illustrated book, The California Missions, published by the Getty Conservation Institute (Kimbro and Costello 2009). Begun by friend and historian Edna Kimbro, who died before its completion, it was given the International Book Awards' Grand Prize for Non-Fiction in 2010.

Looking back, I feel very fortunate to have had such an interesting and rewarding career and am grateful to have shared it with so many wonderful colleagues.

\section{References}

Costello, Julia G

1983 Melones: A Story of a Stanislaus River Town. U.S. Department of the Interior, Bureau of Reclamation, Mid-Pacific Region, Sacramento, CA.

Costello, Julia G., and Mary L. Maniery

1988 Rice Bowls in the Delta: Artifacts Recovered from the 1915 Asian Community of Walnut Grove, California. Cotsen Institute of Archaeology Press at UCLA, Los Angeles, CA.

Costello, Julia G., and Phil Walker

1987 Burials from the Santa Barbara Presidio Chapel. Historical Archaeology 21(1):3-17.

Kimbro, Edna E., and Julia G. Costello 
2009 The California Missions: History, Art, and Preservation, Tevvy Ball, contributor. Getty Conservation Institute, Los Angeles, CA.

Publisher's Note Springer Nature remains neutral with regard to jurisdictional claims in published maps and institutional affiliations. 